\title{
QUALITY AFFORDABLE HOUSING CONCEPT: CASE STUDIES IN MEHR, IRAN, DHARAVI, INDIA, AL-SHARQ, JORDAN AND BASHAYER AL-KHAIR, EGYPT
}

\author{
ADEL EL-MENSHAWY \& AMR SHARABY \\ Arab Academy for Science, Technology \& Maritime Transport, Egypt
}

\begin{abstract}
The provision of adequate, good or quality housing for the population has always been a major challenge and aim for many nations in the world particularly the developing countries. However, most of these countries suffer from the same problem, the gap in the low-income housing sector is increasing day after day. Moreover, the main problem is that the population is increasing, and their needs are changing constantly. Governments all over the world are trying to reach most of affordability ratio in the housing sector for low-income. Yet there are many concepts that should be considered such as Quality Affordable Housing Concept. The paper has a main aim which is to evaluate affordable housing projects based on quality affordable housing criteria. Therefore, qualitative, quantitative, analytical and comparative methodology are chosen to reach the paper's aim. Four housing projects selected to be case studies for this paper: Mehr in Iran, Dharavai in India, AlSharq in Jordan and Bashayer Al-Khair in Egypt.
\end{abstract}

Keywords: affordable housing, low-income housing, quality affordable housing, housing market, low-income, affordability.

\section{INTRODUCTION}

Housing is an essential aspect in life. In 1977 Lazenby suggested that three ways that architects, planners and social scientists can work together in developing a framework for the provision for good quality affordable housing:

a) The architect or planner must gather information which will be integrated to produce good quality affordable housing according to the needs of residents.

b) Architects and social scientists have to collaborate in the evaluation of a residential environment from the point view of the users.

c) Architects, planners and social scientists should gather their talents in efforts to set those dimensions of housing and residential areas which contribute to the overall quality of life.

Therefore, low-income housing is one of the essential structures of any housing development strategy. However, affordability on the housing sector turned into an obstacle of the housing development process in especially in Egypt and India [1].

This study aims to analyze four different affordable housing projects based on the criteria of quality affordable housing. The researcher had to choose qualitative and quantitative methodologies to outcome the criteria of quality affordable housing. Also, analytical, field and comparative methodologies used to clarify case studies of this paper. The case studies selected according to several aspects: similar scale of the projects, number of households, number of housing units, aim of the projects, and type of affordability.

\section{CRITERIA FOR QUALITY AFFORDABLE HOUSING}

The provision of adequate, good or quality housing for the population has always been a major challenge and task for most nations in the world particularly the developing counties, 
Egypt, India, Iran and Brazil. As such various measures have been undertaken towards this end [2].

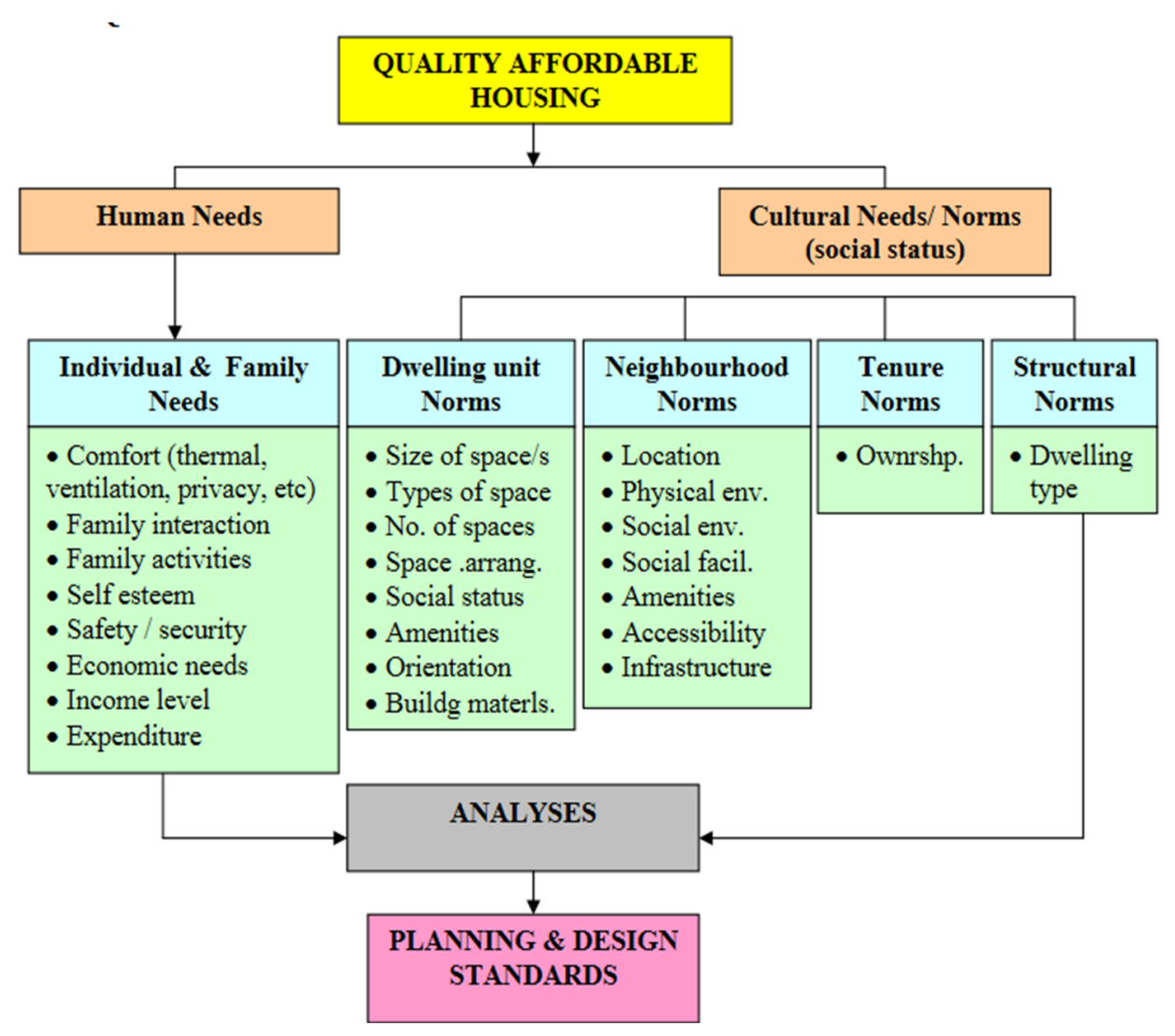

Figure 1: Criteria of quality affordable housing [2].

\section{CASE STUDIES}

\subsection{Case of Mehr Housing Project, Iran}

Mehr projects are a housing for low-income, constructed in 2007. These projects constructed in three locations: new cities, lands around cities and old areas to facilitate modernization and improvement. Mehr is still going project aimed to reach one million and five thousand of housing units. These number of units will cover six million population of the country, which is approximately $12 \%$ of urban population. Ministry of housing, Housing Foundation, Ministry of Cooperatives, Central Bank, Municipalities and Central insurance collaborated altogether to construct Mehr Housing Projects [3].

This project main aims are to bring equality in between supply and demand of housing by omitting the land price, housing for low-income people and poor people, control and prevent the skyrocketing the prices of lands and housing, housing boost production and increase production volumes of housing and reducing the cost of housing (Rent, mortgage 
and buy). Also, it is aimed to give solution for the future housing needs, justice in access to quality affordable housing [3].

Therefore, the researcher had to choose Mehr to evaluate the project using quality affordable housing criteria. First criteria: Location and accessibility: In Mehr housing projects the ones that locating inside of the cities have much more benefit than the ones that are located outside of the cities. They have better access to public transportation but the houses that located outside the cities suffer from the lack in transportation. However, most of the households in suburbs houses are workers in other cities and the big cities next to these suburbs' projects, the government is ignoring the shortage of transportation system.

Second criteria: Location features: Mehr Projects that are located in the cities have access to different facilities such as educational, entertainment, bazars, sport and health facilities. They also have access to gas, electricity, water, telephone and sewage system. However, the projects which are located outside the cities suffers from lack of access to entertainment, health, educational, bazars and sport facilities. Also, some of them have lack in gas, water, electricity and telephone.

Third criteria: Safety and security: One of the most important factors that should be considered in housing design in Iran is earthquake. Unfortunately, most of the housing units are not constructed regarding the natural factors. Imagining, if there are any natural disasters happened in Mehr projects, there will be no facility can help and support the households of these projects. Mehr housing projects located in Tabriz, Hadishahr and Marand were not designed by considering the environment factors. Due to Neyshaboor earthquake in 2017, most of Mehr housing units were destroyed, Iran government created an insurance program for all Mehr projects.

Fourth criteria: Public open spaces and recreational activities: The projects that are located in the cities have access to park and green areas. However, in projects in suburb areas, they have lack in public areas, gardens and playground for children.

Fifth criteria: Plan layout and functions: There are different plan types in Mehr housing projects as shown in Fig. 2. These apartments are categorized as high rise and medium rise buildings. The plans of Mehr housing projects should be suitable for the population density and also culture of the city. They are designed by considering the climatic factors of different cities and sun orientation plan of two types of housing unit, one of them 75 square meter and the other 62 square meter.

Sixth criteria: Physical features: the designer of the housing units had to consider any natural disaster such as earthquakes. On the other hand, the project typed as quality affordable housing for low-income people. However, most of contractors who participated in the project chose to use low quality construction materials for the own money saving, households' satisfaction ratio is low. Generally, In Mehr housing projects there is a semi open balcony for each unit. In parallel to the religion of this country, generally families have more privacy and they are not using these semi open spaces as a socializing area [3].

\subsection{Case of Dharavi Housing Project, India}

This example will focus on Navrang in Dharavi, India to be fitting with this thesis's study scale. Navrang has about 300 households. The Indian government chose to upgrade this area, which mostly contains shanty houses.

Indian government aimed to upgrade quality of life of the regional household through providing the basic human needs in the community and eradicating shanty houses in the area. Also, one of the most essential aims of this project is to decrease unsafe areas in 


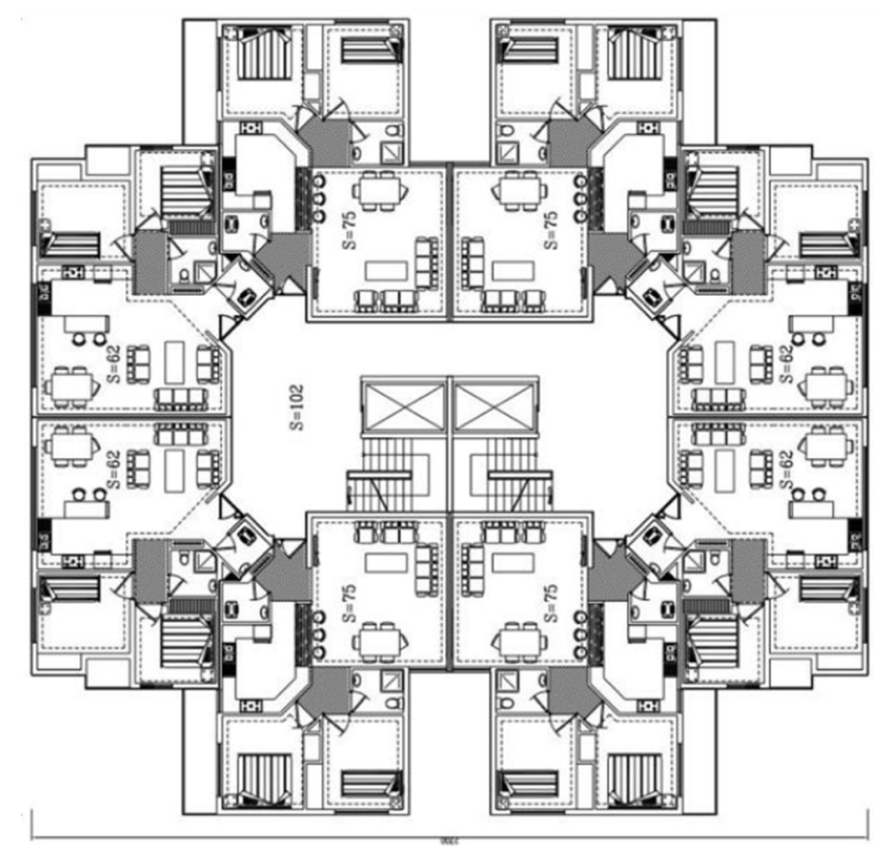

Figure 2: Typical floor plan of Mehr housing [8].

Dharavi. Thus, Indian government aimed to increase livability in Dharavi through providing more services for the community, such as educational, transportation, recreational areas, shopping malls, kids gardens, and health care centers [4].

Therefore, the researcher had to choose Dharavi to evaluate the project using quality affordable housing criteria. First criteria: Location and accessibility: Dharavi housing project located in central location in the city, for higher accessibility and integrated urban form. Also, the project has a good access to transportation facilities and walkable distance between housing units and services. The distance between the housing project and workplaces is a walkable distance.

Second criteria: Location features: Because of the project location, it is high accessibility to community services such as educational, transportation, recreational areas, shopping malls, kids' gardens, and health care centers as shown in Fig. 3. However, Indian government supplied most of community services facilities, these facilities considered as a low-quality service and need to improve.

Third criteria: Safety and security: Livable urban structure aims to reduce crime percentage in the project and establish the sense of belonging. Also, Government aimed to remove unsafe areas in Dharavi to provide sense of safety and community eye. However, Social rejection for Dharavi households is affecting directly on crime percentages.

Fourth criteria: Public open spaces and recreational activities: The housing blocks that are located in the cities have access to park and green areas. However, no maintenance for public spaces, recreational areas and gardens is the main aim for decrease quality of these services. 


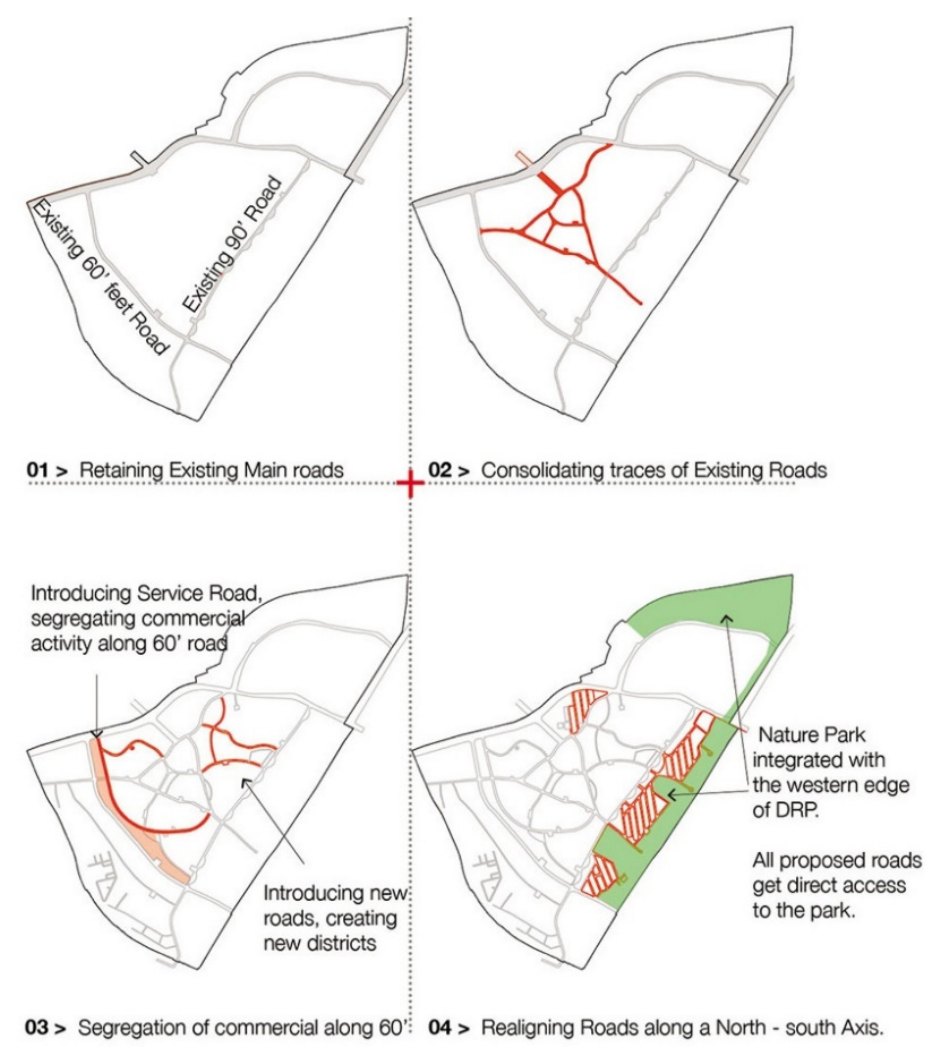

Figure 3: Dharavi project master plan analysis [7].

Fifth criteria: Plan layout and functions: Skeleton reinforced structure system is the used construction method in Dharavi housing project. It provided two different housing units with the ability to be extended which shows its flexibility approach: $49 \mathrm{~m}^{2}$ housing type and $24.5 \mathrm{~m}^{2}$ housing type.

Sixth criteria: Physical features: As shown in Fig. 4, a very flexible design and ability to extend are the most important factors in the housing units. There is an Increase quality of life through providing a new infrastructure for the community, however, it is affecting on the public health by indirect ways. And socio-spatial segregation is highly shown in Dharavi [4].

\subsection{Case of Bashayer Al-Khair, Egypt}

This project, which is a developed area of "Ghait Al-Enab", is recently one of the leading distinguished national cases, represented in the Egyptian Armed forces and Alexandria Town Council. They cooperated with the society to implement the strategy not only to develop Ghait Al-Enab to Bashyer Al-Khair, but also to replace it with efficient affordable housing for low/middle-income categories [5].

The strategy had to be set to encounter those challenges and problems to include a detailed study of all urban dimensions without ignoring the social and development dimensions. This strategy is summarized in several points, including [5]: 


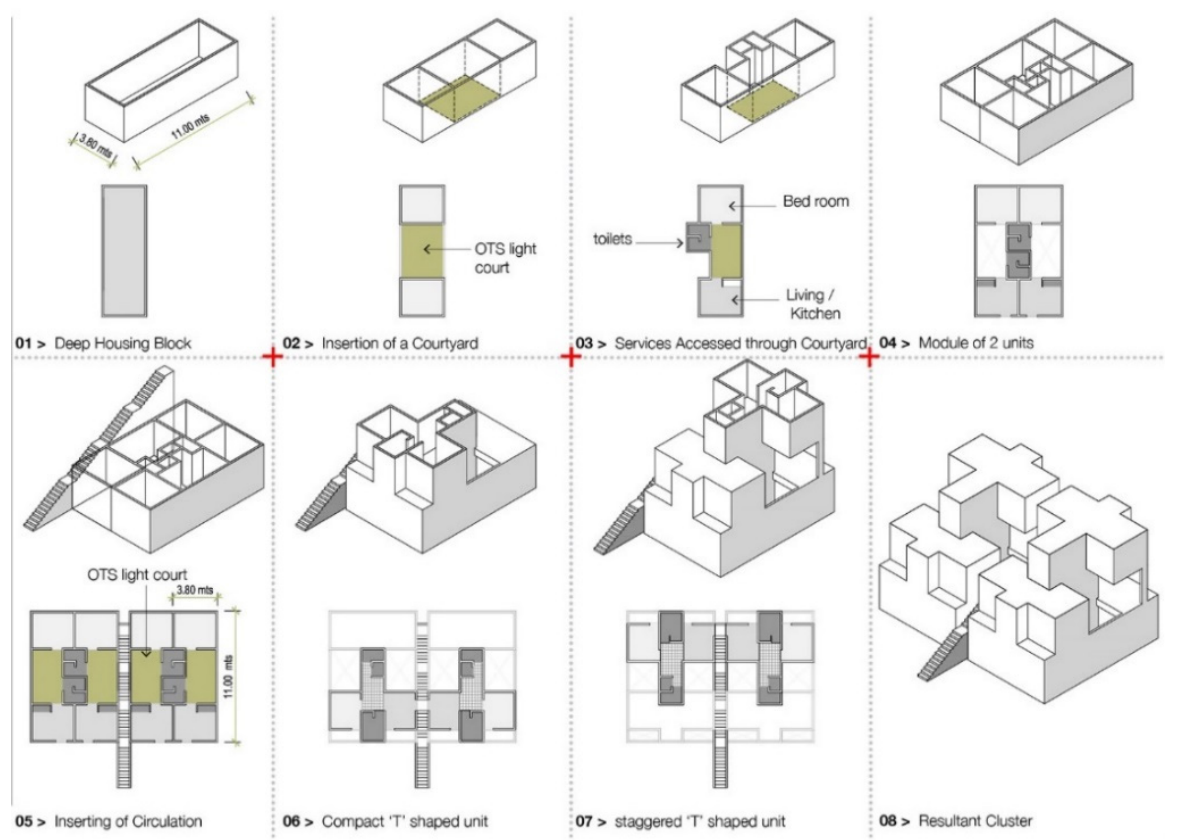

Figure 4: Analysis of Dharavi project and housing units [7].

1. The development and upgrade of urban standard and the improvement of the quality of life as well as environment that surround these families.

2. The achievement of a comprehensive development of families in all fields and qualifying them for living in newly developed societies.

3. Enabling the community members in those areas to achieve self-reliance to find solutions for their problems by self-efforts and by cooperation with the states represented in the armed forces.

4. Training youth and women to gain skills and experiences that would help them achieve a material return to ensure them the means of a decent life.

5. The invitation was made for social participation and participation of businessmen along with volunteers as an inevitable necessity to encounter the problem of low potentials and resources that are encountered.

Therefore, the researcher had to choose Bashyer Al-Khair to evaluate the project using quality affordable housing criteria. First criteria: Location and accessibility: The project is located in one of the districts of East Karmouz in Alexandria, which is popular area with several tourist attraction sites, including the Mast Column. In addition, there are monumental tombs of Kom Al-Shoqafa. Karmouz shares a border in the South with Mariot Lake and in the east with Moharram Bek District which is adjacent to it. It is bordered in the north by Labban and Attar districts.

Second criteria: Location features: While Ghayt Al-Enab was transferred to deteriorating area because of poor planning, in addition to cracking of the old units that were situated one hundred years ago, the area was one of the political leadership's priorities to transfer it to new residential units that provide all services to enable average citizens to live their safety and security. 


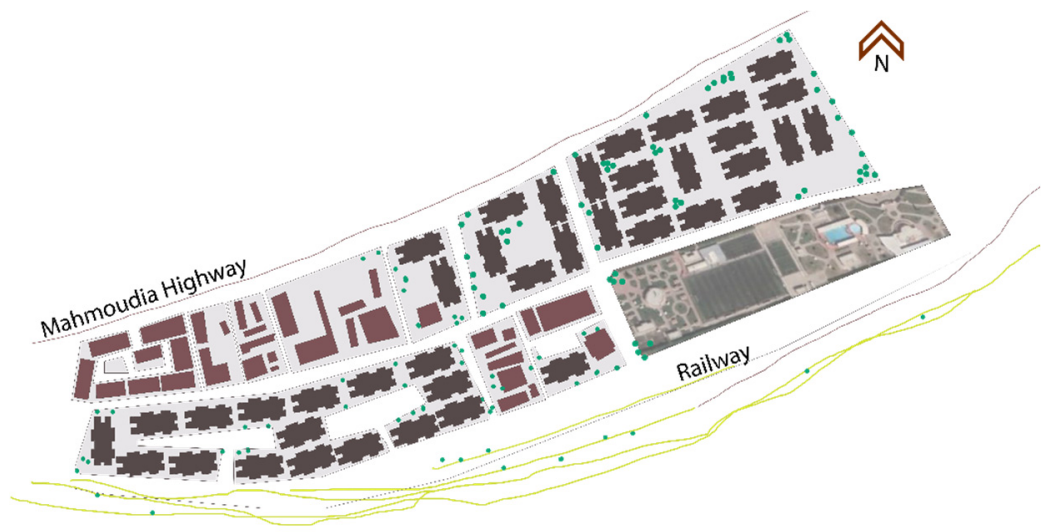

Figure 5: Site plan of Bashayer Al-Khair [5].

Third criteria: Safety and security: Ghayt Al-Enab reached a state of deterioration and severe urban underdevelopment. The intensity of the deterioration increased by occupation of general spaces that surround the case study by many families. This resulted in a relatively high increase rate in such areas where the ownership of lands and spaces in that area is commonly without the control of the government of Egypt.

With the critical social call for development of such deteriorating residential areas as a direct result of many social, security, political and other direct reasons. The aspect that raised the concern of the potential contribution of Egypt represented in the armed forces and businessmen in the removal of the dust of the surrounding environment. The government of Egypt has set the borders of the development area, which is 12.3 feddan.

The Government of Egypt created a price list for the local residents of Ghayt Al-Enab and another one for the new residents of Bashyer Al-Khair:

a) The local residents of Ghayt Al-Enab:

1. The payment of a monthly fee to own the housing unit.

2. Paying 50EGP per month for maintenance of electricity, elevators, water pumps and other items.

b) The new residents of Bashyer Al-Khair:

1. The unit's price is between 250,000 LE and 300,000 LE. This price could increase according to the unit's location.

Fourth criteria: Public open spaces and recreational activities: The project includes a charity hospital (Gamal Hammad Central Charity Hospital) which is equipped with 150 beds and outpatient clinics community, dialysis unit and an emergency unit. Besides the center, there is a training center and a workshop. In front of them to the left, there is a big branch of the National bank of Egypt and beside it is the consumer complex and retail market that contains 58 stores, malls, and workshops [5].

Fifth criteria: Plan layout and functions: Bashyer Al-Khair contains 34 residential buildings with a total of 1,632 residential units and an area of $90 \mathrm{~m}^{2}$ per unit as shown in Fig. 6 . This includes the infrastructure, finishes and preparation so that the building consists of ground floor +11 floors with electric elevators [5]. 
Sixth criteria: Physical features: Reinforced concrete skeleton system is the construction method of the project; therefore, each housing unit consists of [5]:

1. A living room which is the space where all possible living activities can take place such as sitting, television, food and sometimes sleeping. Rooms of multiple living use, including bedrooms, a kitchen and a bathroom are distributed in it.

2. Bedrooms: each residential unit contains three bedrooms (girl's bedroom, boy's bedroom, parents' bedroom) that open to the living room.

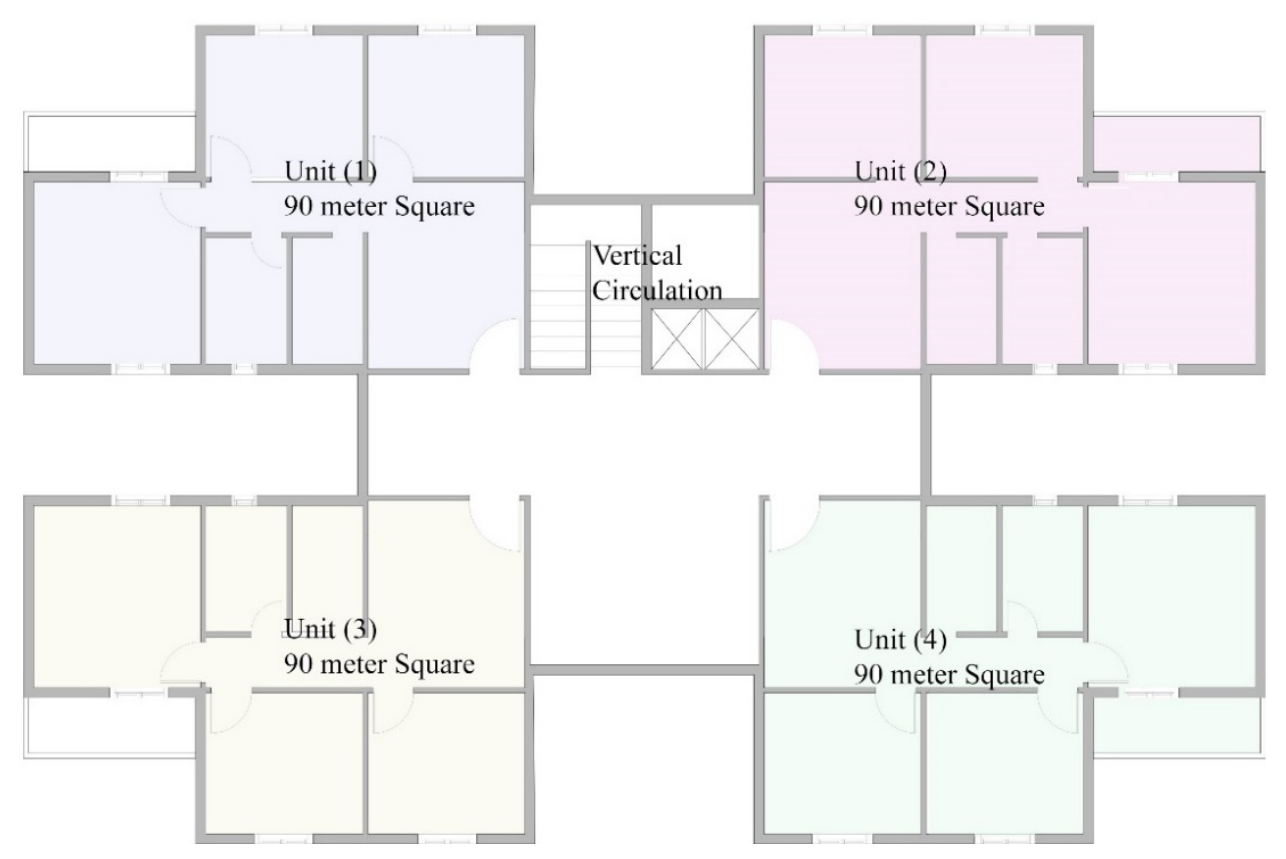

Figure 6: Typical plan of Bashayer Al-Khair [5].

\subsection{Case of Al-Sharq project, Jordan}

Al-Sharq housing project is a massive scale affordable housing project in Jordan that gives a solution to solve the population growth. The government transformed site of the military camps in Zarqa to quality housing project. It was chosen to measure the degree of housing quality that Al Sharq housing project obtains in terms of residential satisfaction with the social, environmental and physical conditions of this housing project [6].

This project aims to create a modern, integrated city, that forms a major urban landmark and a natural extension of the city of Zarqa. Al-Sharq housing project development site mounts 2,500 hectares and is divided into six construction phases. The constructed phase of the project covering 250 hectares is located along the Amman-Zarqa highway. It includes a set of districts [6]:

1. Five residential districts -135 hectares;

2. A peripheral commercial district -40 hectares; and

3. A central commercial distract -75 hectares. 
4. As for the main components of the project plots are, namely, 925 residential plots, 235 commercial plots, seven mosques, seven public parks, seven schools, seven kindergartens, one health center, one hotel and one youth center.

5. The types of implemented housing in this project are, namely, housing complex, row housing and detached houses/villas.

Therefore, the researcher had to choose Al-Sharq to evaluate the project using quality affordable housing criteria. First criteria: Location and accessibility: Walkable neighborhood: pedestrian friendly exclusivity and privacy green spaces Has a transport system, that is, environmentally friendly. Accommodates multi-modal transportation (i.e., pedestrians, bicyclists and drivers) [6].

Table 1: Detailed analysis of Al-Sharq project land use [6].

\begin{tabular}{|l|c|c|}
\hline Land use & Area (hectare) & $\mathbf{( \% )}$ \\
\hline Housing & 91.22 & 36.30 \\
\hline Commercial & 47.85 & 19.4 \\
\hline Public services & 17.04 & 6.78 \\
\hline Roads & 74.48 & 29.64 \\
\hline Gardens and open spaces & 20.70 & 8.24 \\
\hline Total & 251.29 & 100 \\
\hline
\end{tabular}

Second criteria: Location features: the row housing as an alternative configuration that guarantees privacy, freehold ownership and also provides individual gardens for each dwelling. At present, there are 170 row houses built around an open communal garden. However, Detached homes contain an open area, a specific area with limited roof and villa where people live. These homes are highly valued across the world more than any other kind and are considered the dream residence. These types of houses enjoy significant advantages such as:

1. The family level of privacy and freedom is maintained, as single-unit (detached) properties are segregated from each other and each land parcel is given to a particular family; tranquility is prevalent; and little or no noise pollution from neighboring homes.

2. Nowadays, due to the increased population, such properties are rarer in areas where new residences comprise mainly of apartment buildings.

Third criteria: Safety and security: Over $40 \%$ of the residents were dissatisfied, with the lack of safety, security and privacy being the most significant failing. However, $30 \%$ of our sampled residents were satisfied with some of the social factors including the sense of place, of community and belonging and good social relations between the residents themselves.

Fourth criteria: Public open spaces and recreational activities: the first three characteristics that are considered priority for the physical dimension, and which could be included in the Al-Sharq city master plan. These characteristics are, namely, abundance of parking lots, pedestrian-friendly neighborhood and multi-modal transportation. Moreover, this survey shows that the most suitable physical facilities are: health services; educational services (primary schools); and nearby commercial services [6].

Fifth criteria: Plan layout and functions: Apartments building height five floors where family members live as neighbors within the defined area. It also contains public services 
and recreational places that are commonly used by the residents. Nowadays, the vast amount of urban society lives in these apartments due to high population density and the cost of land. Second type of residential units, attached housing as an alternative configuration that guarantees privacy, freehold ownership and also provides individual gardens for each dwelling. At present, there are 170 attached houses built around an open communal garden.

However, detached housing contains an open area, a specific area with limited roof and villa where people live. These homes are highly valued across the world more than any other kind and are considered the dream residence. These types of houses enjoy significant advantages such as: the family level of privacy and freedom is maintained, as single-unit (detached) properties are segregated from each other and each land parcel is given to particular family; tranquility is prevalent; and little or no noise pollution from neighboring homes.

Sixth criteria: Physical features: Reinforced concrete skeleton system is the construction. The project has several partitional, the researcher described them into the following

a) Provide large green areas, gardens, playgrounds, hiking and sitting Contemporary urban lifestyle.

b) Provide an efficient and organized public infrastructure and services.

c) Participation in collective groups and networks in the community.

d) Has design and architectural features that are visually interesting.

e) Contemporary urban lifestyle.

\section{COMPARISONS BETWEEN THE CASE STUDIES}

Housing concept should perform a double function: (1) the interior, one of providing a place where a household of different age, sex, education, occupation, intellectual modes and values can meet in harmony; and (2) the exterior, one of providing meeting grounds for groups of households and for the healthy and enjoyment enrichment of their lives and the life of the community.

However, a group of World Health Organization experts defined housing as:

"The residential environment, neighborhood, micro-district or the physical structure that mankind uses for shelter and the environments of that structure, including all the necessary services, facilities, equipment's and devices needed for the physical and mental health and social well-being of the family and the individuals".

In economic term, housing is categorized as a commodity which has a market value and can be bought and sold. Through housing is reflected the type of household, high/middle/ low household, and affordability to reach a certain level of quality of life.

Governments all over the world is trying to reach most of affordability ratio in the housing sector. However, quantity of housing units is directly affecting on the affordability ratio, the concept of quality affordable housing should be considered. The paper aims to evaluate affordable housing projects based on quality affordable housing criteria.

\section{CONCLUSION}

Housing is a complex and multi-dimensional phenomenon. Therefore, in developing a model which can be used as a guideline for design and provision of quality affordable housing would require analysis of the various parameters or perspectives particularly with respect to the individual and family needs, the physical, physiological, economic, affordability, social, cultural, dwelling unit or space requirement, environmental, 
Table 2: Comparison between affordable housing projects based on quality affordable housing criteria.

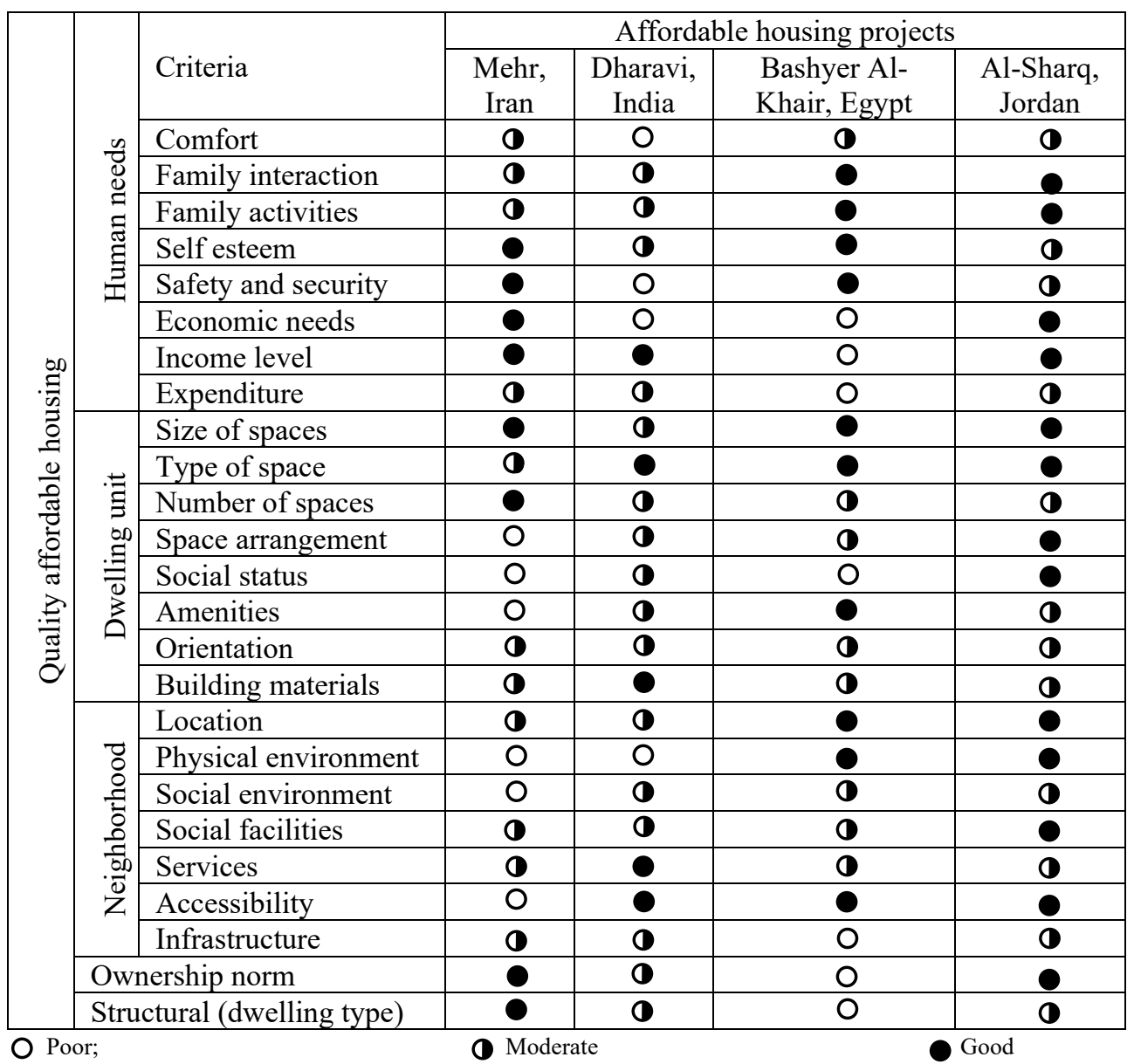

neighborhood, location, tenure, structural norms and also psychology of the occupants, which constitute the pertinent parameters for the formulation of standards or criteria for the planning and design affordable housing.

\section{REFERENCES}

[1] Ibrahim, M.R., How do people select their residential locations in Egypt? The case of Alexandria. Cities, 2017.

[2] Noor Sharipah, S.S., Quality affordable housing: A theoretical framework for planning and design of quality housing. Journal of Techno-Social.

[3] Maryam Ghasemi, N.O., A discussion on affordable housing projects: Case study Mehr housing, Iran. Journal of Contemporary Urban Affairs, pp. 137-145, 2018.

[4] Dharavi Township Redevelopment Master Plan, Mumbai, India, 2013.

https://www.federaldesigngroup.com/projects_viewer.php?pro=Dharavi-TownshipRedevelopment-Master-Plan,-Mumbai,-India $\&$ di=master_planning. 
[5] Sharaby, A., Hemeida, F. \& Shafik, S., Affordability as an obstacle in the housing development process in Egypt for low-incomes: Case of Bashayer Al-Khair. Wessex, eds W.I.S. Syngellakis, \& U.o.S. Hernández, 2020.

[6] Al Shawabkeh, R.K., Al Zouby, A.M., Rjoub, A. \& Alsamdi, M., Evaluating the satisfaction rate for affordable housing in nongated residential area (NGR): The case of Al-Sharq Housing Project in Zarqa-Jordan. Emerald, pp. 192-210, 2020. https://www.emerald.com/insight/1753-8270.htm.

[7] G7 Architects, Re-Inventing Dharavi. http://www.g7architects.in/v3/res_housing _ redharavi.php.Accessed on: 28 Oct. 2021.

[8] Esruq, L. \& Othuman, M. Criteria for affordable housing performance measurement. EDP Sciences, 2014. 